\title{
LEGAL PROTECTION AGAINST SALE AND PURCHASE AGREEMENT OF BUILDING USE TITLE IN THE EVENT OF DEFAULT
}

\author{
I Nyoman Gede Murdiana, Program Pascasarjana Universitas Pendidikan \\ Nasonal, e-mail: nyomanadv@gmail.com \\ A.A.A.N Sri Rahayu Gorda, Universitas Pendidikan Nasonal, \\ e-mail: srigorda@undiknas.ac.id \\ doi: https://doi.org/10.24843/KS.2020.v09.i01.p02
}

\begin{abstract}
An agreement will not always be able to run according to the agreement of the parties. Certain conditions can be found, such as, the occurrence of various things that result in an agreement cannot be implemented, namely the buy-back right by the seller which has been agreed upon and results in losses for the buyer and on a court decision that sentences the seller to carry out the agreement seven days after the verdict, but the implementation of the sale and purchase agreement has not yet been carried out. This paper examines the legal protection for the buyer against the sale and purchase agreement for building use rights in terms of default. This type of research is a normative juridical legal research applying a case study approach and statue approach. The preventive legal protection for the buyer, namely legal protection is by requesting for irrevocable power of attorney, referred to as absolute power of attorney. Meanwhile, repressive legal protection is legal protection after the occurrence of a dispute, namely based on the consideration of a judge's decision which can provide a sense of certainty and justice to the aggrieved buyer.
\end{abstract}

Keywords: Legal Protection, Sale and Purchase Agreement, Default

\begin{abstract}
ABSTRAK
Suatu perjanjian tidak selamanya akan dapat berjalan sesuai dengan kesepakatan para pihak. Kondisi tertentu dapat ditemukan terjadinya berbagai hal yang berakibat suatu perjanjian tidak dilaksanakan yaitu dengan hak membeli kembali oleh penjual yang telah disepakati dan mengakibatkan kerugian bagi pihak pembeli dan atas putusan pengadilan yang menghukum pihak penjual untuk melaksanakan perjanjian tujuh hari setelah putusan, akan tetapi pelaksanaan perjanjian jual beli tersebut belum juga terlaksana. Jenis penelitian ini adalah penelitian hukum yuridis normatif dengan menggunakan pendekatan studi kasus dan pendekatan perundang-undangan. Perlindungan hukum secara preventif bagi pihak pembeli yaitu perlindungan hukum yaitu permintaaan pemberian kuasa yang tidak dapat ditarik kembali yang disebut surat kuasa mutlak. Sedangkan perlindungan hukum secara represif adalah perlindungan hukum setelah terjadinya sengketa yaitu berdasarkan pertimbangan putusan hakim yang bisa memberikan rasa kepastian dan keadilan terhadap pembeli yang dirugikan.
\end{abstract}

Kata Kunci : Perlindungan Hukum, Perjanjian Jual Beli, Wanprestasi

\section{Introduction}

\subsection{Background of Problem}

Earth, water and natural resources contained therein, in this case, are controlled by the state and maximally used for people's welfare. Article 33 paragraph 3 of the 1945 Constitution of the Republic of Indonesia means that the earth, water and space and the 
wealth contained therein are gifts that should be grateful from God Almighty to all the people of the Indonesian nation.

The human need for a house here requires land, which is an important role in human life both as a source of life and as a form of development to be used for the welfare of all Indonesian people. Land is one of the main needs of humans and can also be used for human activities, such as shelter and development ${ }^{1}$ because land has a dual function, namely as a social asset and as a capital asset. As social asset, land is a means of binding social unity among the Indonesian people. As capital asset, Land has grown as a very important economic object, not only as a commercial material but also as an object of speculation. On the one hand, land must be used and utilized maximally for the welfare and prosperity of people and on the other side its sustainability must be preserved. ${ }^{2}$

Various disputes are often intertwined within the community, both between individuals and groups of citizens and industry, especially between the community and the government. If the dispute cannot be resolved amicably, so that one of the parties who feels that his rights have been disturbed by the other party is forced to bring a problem or file a claim for his right before the law in order to obtain a legal dispute resolution decided by the competent judge based on his legal considerations, in accordance with with the law or applicable law. ${ }^{3}$

Law number 5 of 1960 Article 35 paragraph 1 of the Basic Agrarian Law, building use title is the right of ownership to establish and own buildings on land that is not his own, with a maximum period of 30 years and can be extended for 20 years, can be transferred and assigned to another party. Pursuant to Article 21 of Government Regulation No. 40/1996, lands which can be granted with a building use title are State land, management rights land and property rights land. 4 Transfers of building use title can occur for several reasons. This is regulated in Article 34 paragraph 2 of Government Regulation Number 40 of 1996. The transfer of building use title occurs because of sale and purchase, exchange, equity participation, grants, and inheritance.

Seeing Article 33 of Government Regulation number 40 of 1996 paragraph 1, Building Use Title can be used as collateral for debt with the charged of mortgage rights and Law number 4 of 1996 concerning mortgages over land and objects related to land, hereinafter is abbreviated as Law concerning Mortgage Right (UUHT). The existence of UUHT is a mandate of Article 51 of Law number 5 of 1960 concerning Basic Agrarian Law, which reads that "Mortgage can be imposed on Freehold, Cultivation Rights, and Building Use Title" 5 .

In practice, when mortgage provisions are still in place as collateral for the land, the prohibition for creditors to automatically own the collateral has been smuggled in or avoided by using a sale and purchase agency with repurchase rights as regulated in

1 Hamdaliah, Hamdaliah. "Perlindungan Hukum Bagi Pihak Pembeli yang Beritikad Baik dalam Jual Beli Tanah." Lambung Mangkurat Law Journal 1, no. 2 (2016): 150-169.

2 Achmad Rubaie, Hukum Pengadaan Tanah Untuk Kepentingan Umum, ( Malang: Bayumedia, 2007), 1

3 Pramithasari, Karina. "Analisis Yuridis Terhadap Wanprestasi Perjanjian Jual Beli Tanah Di Kota Batam (Studi Kasus Nomor: 26/Pdt. G/2011/PN. BTM)." PETITA 3, no. 2 (2017).

4 Surat Menteri Negara Agraria/Kepala Badan Pertanahan Nasional, tentang Agunan Sertipikat tanggal 17 September 1998, Nomor 630.1-3433.

5 Hendri Budiyanto, Pembebanan Hak Tanggungan Terhadap Hak Guna Bangunan Dalam Perubahan Status Menjadi Hak Milik, Jurnal Repertorium, ISSN:2355-2646, Edisi 3, Januari-Juni 2015, h.32 
Article 1519 to Article 1532 of the Indonesian Civil Code. Sale and Purchase with the right to repurchase is valid as long as it complies with the legal requirements of an agreement as stipulated in Article 1320 of the Civil Code. This sale and purchase agreement is used as the basis for granting the right to repurchase and is used to avoid a principle in the guarantee law, and therefore its authenticity is surely questionable. ${ }^{6}$.

Pacta Sun Servanda's theory illustrates that an agreement is legally drawn up and according to Indonesian law, so that it is assumed to be an agreement drawn up in good faith, so the clauses in such agreement bind the parties who draw it, where the binding power is the same as the binding power of a law, and also the implementation of such an agreement may not be carried out because it is detrimental to the opposing party in the agreement or to a third party beyond the parties to the agreement. ${ }^{7}$

The agreement made by the parties cannot always run according to the desired agreement. In certain conditions, it may be found various things resulting in an agreement cannot be executed by one of the parties and by order of a court decision. The implementation of a land sale and purchase agreement is necessary for further study and considering that a sale and purchase agreement is a legal act preceding the process of transferring land rights. A sale and purchase agreement of land contains the rights and obligations of the parties drawing up the agreement, so if the matters that have been agreed in the sale and purchase agreement are not carried out by one of the parties drawing it up, ${ }^{8}$ it is said that default has occurred, as in occurred in South Jakarta in the case No. 678 / Pdt.G 2014 / PN.Jkt.Sel., dated 3 September 2015. This agreement was not implemented due to the inability of the seller in this case, namely Mrs. I to buy back or to find a buyer for the land and building rights to build with the certificate of building use title which has been in due date and did not assist the buyer in transferring the rights of the land and buildings in the sale and purchase agreement for certificate with Building Use Title that have been previously agreed with the buyer, namely Mr. A. The case was that the Sale and Purchase Agreement drawn up by the parties before Notary, Land Deed Conveyancer on 12 February 2008 under the Deed of Sale and Purchase Agreement of a plot of land with Building Use Title, and in this case Mister A had paid in full to the seller Mrs. I at the same time when the Deed of Sale and Purchase Agreement was signed. After implementing the Purchase and Purchase Agreement Mrs. I made a Mortgage on the certificate of Building Use Title to Mister A, dated 23 July 2009. Whereas, in the Sale and Purchase Agreement, Mrs. I was given the opportunity to buy back the land and building on 13 August 2008 and Mrs. I was given the opportunity to find a buyer before the due date. However, upon 6 months given the opportunity to buy back the land and/or to find out a buyer by Mister A, but this opportunity was wasted by Mrs. I for a long period of time until a lawsuit was made on 12 November 2014. Mr. A has often reminded Mrs. I, to immediately carry out the contents of the sale and purchase agreement, but Mr. A's warning was in vain. Since Mrs. I had defaulted or broken her promise, Mr. A suffered a loss where Mr. A could not control the land and

6 Suharnoko, Hukum Perjanjian Teori Dan Analisis Kasus, Cetakan ke 9, ( Jakarta: Kencana, 2015), 28-29

7 Ni Made Utami JayantiI Nyoman DarmadhaA.A. Sri Indrawati, Batalnya Pengikatan Perjanjian Jual Bei Tanah Dan Bangunan Karena Perbuatan Melawan Hukum Yang Dilakukan Oleh PT. Srikandi, Fakultas Hukum Universitas Udayana, jurnal kerthasemaya, VOL 5 NO 1 2017, h. 4

8 Muljono, Bambang Eko. "Perlindungan Hukum Bagi Pihak Penjual Terhadap Pihak Pembeli Wanprestasi Dalam Ikatan Jual Beli Tanah." Jurnal Independent 4, no. 2 (2016): 41-46. 
the buildings thereon from 13 August 2008 until the passing of verdict in the court case on 3 September 2015 where the ruling was that to sentence Mrs. I to carry out the agreement 7 (seven) days after the verdict was pronounced. In 2018, the implementation of the agreement has not been carried out by the seller. Whereas, if the land and buildings were handed over and/or leased out, Mr. A can get the proceeds of the land and building. Based on the problem of the case example above, the writer is interested in taking the title Legal Protection Against the Sale and Purchase Agreement of Building Use Title in the Event of Default. In accordance with the provisions of Articles 1266 and 1267 of the Civil Code, with the fulfillment of the conditions for the continued implementation of the agreement or the conditions for cancellation, the land sale and purchase agreement can be continued or terminated providing that it must be returned to the original condition as at the time the agreement was signed. Then, the court decision must fulfill a sense of justice and legal certainty for the injured party, namely the buyer.

\subsection{Formulation of problems}

Based on the description of the above background, several problems can be formulated, including:

1. How is the agreement between the parties regarding the sale and purchase agreement for building use title?

2. How is the legal protection for the buyer against the sale and purchase agreement for building use title in the event of default?

\subsection{Purpose of Writing}

This study aims at understanding science, especially in the field of contract law related to legal protection of sale and purchase agreement for building use title in the event of default. Recognizing and studying how the agreement of the parties to the sale and purchase agreement of the building use title, and also to find out and study the legal protection for the buyer who is injured against the sale and purchase agreement the building use in the event of default. The previous studies related to this paper, the legal consequences for the buyer who defaulted and the efforts that the seller could make against the buyer who was in default in the land purchase agreement with the status of building use rights, ${ }^{9}$ in this paper it is different, namely legal protection from the buyer's side of use of buildings.

\section{Methods of Research}

This type of research applies normative juridical legal research related to legal protection to the sale and purchase agreement of building use title in the event of default by using secondary data consisting of primary legal materials, secondary legal materials, and tertiary legal materials. The technique of collecting legal materials supporting and relating to this study is literature study (research library). Document study is a means of collecting written legal materials using content analysis. The analysis is carried out by approaching the case (case approach) relating to the problems faced and elaborated as is which has become a court verdict having permanent legal force, namely: The Verdict of South Jakarta District Court of the Case Number 678 /Pdt.G 2014/PN.Jkt.Sel. By taking

9 Louwson, Deddy. "Wanprestasi Pengusaha Pt. Sinar Hasil Alam Pada Pihak Penjual Dalam Perjanjian Jual Beli Tanah Hak Guna Bangunan Di Kota Pontianak." Jurnal Fatwa Hukum 2, No. 2.(2019), p. 1 
inventory and identifying laws and regulations, then the case is analyzed pursuant to the laws and regulations through law interpretation, then draw conclusions from the results of the analysis to answer the problems to be raised, supported by a conceptual framework in a legal research which includes legal society, legal subjects, rights and obligations, legal events, legal relations and legal objects ${ }^{10}$

\section{Results and Discussion}

\subsection{The Agreement between the Parties regarding the Sale and Purchase Agreement} of Building Use Title

The agreement basically contains information about the identity of the parties drawing up the agreement clearly, there is price, method of payment (term of payment), guarantees and witnesses, surrender of land and buildings, ownership status, process of change or transfer of title to land ownership, taxes, fees and charges, expiration of agreements, settlement of disputes, other matters requested and mutually agreed upon. With the existence of these provisions and clauses, the interests of the parties can be protected and if an achievement of one of the parties is not fulfilled, it proves that there is a negligence in the agreement that has been committed. An agreement legally made where the legal terms of the agreement have been fulfilled and the addition of terms from the parties, the agreement shall be applicable as law for those who draw it up (Article 1338 paragraph 1 of Civil Code). ${ }^{11}$ Pursuant to Article 26 paragraph 1 of Law Number 5 of 1960 concerning Basic Agrarian Law, transfer of building use title and its supervision through sale and purchase as well as other actions are regulated in the Government Regulation.

An agreement legally entered into by the parties shall be applicable as a law for those who draw it up. It means that both parties are obliged to comply with and carry out the agreement that has been agreed upon by them, as they are obeying a law. An agreement cannot be withdrawn or revoked without the consent of another party, as stipulated in Article 1338 paragraph 2 of the Civil Code, namely an agreement cannot be withdrawn other than by the agreement of both parties, or for any reasons that are declared sufficient for said law.

The legal requirements in the agreement are divided into two groups, namely subjective conditions and objective conditions. Subjective terms are regarding the agreement of the parties binding themselves and the competency of the parties drawing up the agreement. Meanwhile, the objective requirements are certain matters and a lawful cause concerning the object described in the contents of the agreement. If these conditions have been met, an agreement is considered valid. If the subjective conditions have not been fulfilled, then either party can ask for the agreement to be canceled or request the agreement to be implemented. The agreement that has been made remains binding providing that it is not canceled by the judge in its decision and at the request of the party having such right to request cancellation or implementation of the agreement. If the objective conditions are not met, the agreement is null and void. An agreement can be canceled by one of the aggrieved parties by submitting to the court to cancel the agreement. Meanwhile, an agreement that is null and void means that the

10 Soerjono Soekanto, Sri Mamudji, Penelitian Hukum Normatif, Cetakan ke 19 (Depok : Rajawali Pers, 2019), 7

11 Akhmaddhian, Suwari, and Asri Agustiwi. "Perlindungan Hukum Terhadap Konsumen Dalam Transaksi Jual Beli Secara Elektronik Di Indonesia." UNIFIKASI: Jurnal Ilmu Hukum 3, no. 2 (2018): 40-60. 
agreement drawing up by the parties is deemed to have never existed.12 The purpose of the parties entering into an agreement for a legal engagement fails.

\subsection{The Legal Protection for the Buyer against the Sale and Purchase Agreement of Building Use Title in the Event of Default}

Sale and purchase agreement of building use title drawn up by the seller and the buyer. The seller and buyer create an engagement binding the parties. The binding of the parties in an agreement made is a legal consequence that must be adhered to after the agreement was drawn up before a Notary as an authentic deed. Many parties, both the seller and the buyer, in the agreement fail to fulfill their performance (default/breach of promise); in the Civil Code, it is an act of default (Article 1238 and Article 1243 of Civil Code). ${ }^{13}$ This act resulted in the other party suffers from both material and nonmaterial losses. The losses suffered by the aggrieved parties to the agreement and considering that Indonesia is a law state, the aggrieved party should have legal protection regardless of social status or race and ethnicity.

A sale and purchase agreement of building use title drawn up based on an agreement cannot be separated from the occurrence of a violation by either party. ${ }^{14}$ One form of these violations is an act that is against the law. The result of an act that is against the law (tort) is the exitence of loss for the aggrieved party. ${ }^{15}$ Such loss must be compensated by the parties who are imposed by law or a court decision to compensate the loss. There are three forms of compensation for unlawful acts uner the law, namely, nominal compensation, compensation indemnity and compensation upon the punishment from court verdict. ${ }^{16}$

Government Regulation Number 24 of 1997 concerning land registration as regulated in Article 37 paragraph 1 means that the transfer of land rights obtained from sale and purchase of land and buildings can only be registered later, if it is proven by an authentic deed drawn up by a Land Deed Conveyancer pursuant to provisions of the applicable laws. Article 19 Paragraph 1 of Law Number 5 of 1960 concerning Basic Agrarian Law is defined as a guarantee of a legal certainty by the government, so the land registration is carried out throughout the territory of the Republic of Indonesia. Article 23 of Law Number 5 of 1960 concerning Basic Agrarian Law states that registration of said land is not only to prove ownership and also for all transfers, its abolition and imposition must be registered so that it can be a strong evidence regarding the abolition of build use title and the validity of transfer and imposition of rights. Article 3 of Government Regulation Number 24 of 1997 where land registration has the objective

12 Saputra, Komang Edy Dharma. "Pembatalan Sertipikat Hak Milik Dalam Jual Beli Tanah Sebagai Akibat Wanprestasi." Jurnal Ilmiah Raad Kertha 1, no. 2 (2018): 1-16.

13 Arina Ratna Paramita, Yunanto, Dewi Hendrawati, Wanprestasi Dalam Perjanjian Pengikatan Jual Beli Tanah Dan Bangunan (Studi Penelitian Pengembang Kota Semarang), Diponogoro Law Jurnal, Volume 5, Nomor 3, (2016), 3

14 Pertiwi, Endah. "Tanggung Jawab Notaris Akibat Pembuatan Akta Nominee Yang Mengandung Perbuatan Melawan Hukum Oleh Para Pihak." Jurnal Ius 6, no. 2 (2018): 246-258.

15 Prayogo, Sedyo. "Penerapan Batas-Batas Wanprestasi dan Perbuatan Melawan Hukum dalam Perjanjian." Jurnal Pembaharuan Hukum 3, no. 2 (2016): 280-287.

16 Ni Made Utami JayantiI Nyoman DarmadhaA.A. Sri Indrawati, Batalnya Pengikatan Perjanjian Jual Bei Tanah Dan Bangunan Karena Perbuatan Melawan Hukum Yang Dilakukan Oleh PT. Srikandi, Fakultas Hukum Universitas Udayana, jurnal kerthasemaya VOL 5 NO 1 (2017) h.4 
of providing legal certainty and legal protection to holders of title over a plot of land and buildings, in this case a certificate of building use title.

The problem that often occurs in the agreement is the occurrence of default in which the seller of the land, in this case, with the right to buy back or assist in finding a buyer, does not carry out this right until the due date of six months. Land seller do not assist in the transfer of the land and buildings right that have been agreed upon either and result in the buyer suffers from very high losses and the loss of profit value that the buyer has expected, namely to lease back the land and buildings to other people. As in the case occurred in South Jakarta in the Case No. 678 / Pdt.G 2014 / PN.Jkt.Sel., dated 3 September 2015. This agreement was not implemented due to the inability of the seller in this case, namely Mrs. I to buy back or to find a buyer for the land and building rights to build with the certificate of building use title which has been in due date and did not assist the buyer in transferring the rights of the land and buildings in the sale and purchase agreement for certificate with Building Use Title that have been previously agreed with the buyer, namely Mr. A. The case was that the Sale and Purchase Agreement drawn up by the parties before Notary, Land Deed Conveyancer on 12 February 2008 under the Deed of Sale and Purchase Agreement of a plot of land with Building Use Title, and in this case Mister A had paid in full to the seller Mrs. I at the same time when the Deed of Sale and Purchase Agreement was signed. After implementing the Purchase and Purchase Agreement Mrs. I made a Mortgage on the certificate of Building Use Title to Mister A, dated 23 July 2009. Whereas, in the Sale and Purchase Agreement, Mrs. I was given the opportunity to buy back the land and building on 13 August 2008 and Mrs. I was given the opportunity to find a buyer before the due date. However, upon 6 months given the opportunity to buy back the land and/or to find out a buyer by Mister A, but this opportunity was wasted by Mrs. I for a long period of time until a lawsuit was made on 12 November 2014. Mister A has often reminded Mrs. I, to immediately carry out the contents of the sale and purchase agreement, but Mister's warning was in vain. Since Mrs. I has committed default or breach of her promise, then Mister A suffered a loss where Mister A could not control the land and buildings thereon from 13 August 2008 until the passing of verdict in the court case on 3 September 2015 where the ruling was that to sentence Mrs. I to carry out the agreement 7 (seven) days after the verdict was pronounced. In 2018, the implementation of the agreement has not been settled. Whereas, if the land and buildings were handed over and/or leased out, Mr. A can get the proceeds of the land and building.

In the case raised as a problem, namely, the buyer did not get the land and buildings having been agreed upon for a very long period of time and the expected profits the buyer, who had paid in full, might obtained from the land and buildings. The seller should have helped in the right transfer of the land with building use title. Thus, in this case, the buyer must obtain legal protection for the sale and purchase agreement that has been violated by the seller. As explained in Article 1457 of the Civil Code regarding sale and purchase, "an agreement whereby one party submits an object, and the other party pays the price that has been agreed upon", the formulation elaborates that the sale and purchase has arisen reciprocal obligations to the parties drawing up the sale and purchase agreement ${ }^{17}$. In addition to legal protection regarding the provision of conditions, namely an absolute power of attorney against the buyer where the

17 Gunawan Widjaja dan Kartini Muljadi, Jual Beli, (Jakarta : Raja Grafindo Persada, 2003), p. 27. 
absolute power of attorney cannot be withdrawn, and the legal protection that can be provided is in theory of

Legal protection according to Phillipus M. Hadjon that legal protection for the people is a government deed that is preventive and repressive in nature.

a. Preventive legal protection aims at preventing disputes, which directs the government deed to be prudent in making decisions based on its discretion. Legal protection is also where the people are given the opportunity to submit their opinions before a government decision takes a definitive form, namely a certainty to those who feel being disadvantaged. ${ }^{18}$

b. Repressive legal protection aims to prevent disputes, including handling them in the judiciary. ${ }^{19}$ Conceptually, the legal protection provided to the Indonesian people is an implementation of the principle of recognition and protection of human dignity based on Pancasila and the principle of a law state based on Pancasila. In essence, every person has the right to legal protection. Almost all legal relationships shall have protection from law.

The comparative theory of the Decidendi Ratio Theory according to Mackenzie, this theory is based on a fundamental philosophical foundation considering all aspects related to the subject matter of the disputed case then looks for laws and regulations relating to the subject of the disputed case as a legal basis in making decisions and judges' considerations must be based on a clear motivation to enforce the law and provide justice for the aggrieved party.

\section{Conclusion}

Based on the results of the research which have been carried out, it can be concluded that: Legal protection for the buyer who has fulfilled the sale and purchase agreement of building use title, in preventive protection, is that the seller should be able to assist the buyer in transferring the seller's rights to the buyer and helping to find out a buyer for the agreed land and building. Furthermore, repressive legal protection in the form of law enforcement, namely judges in deciding a case of default can hand down a decision by considering a sense of fairness and legal certainty for a buyer who feels being aggrieved and include the provision of sanctions, such as fines, compensation when resolving the disputes in court. Regarding the Buyer who has good faith or because one of the parties does not fulfill the achievements as agreed upon can receive compensation in accordance with the provisions of Article 1267 of Civil Code. As a result of the sale and purchase agreement of building use title which is not carried out, the buyer is harmed because he does not get the benefit of using the object that has been paid for to the seller in full, therefore the buyer needs to get legal protection in the form of compensation in accordance with the agreed price along with the losses borne by the buyer against the seller. Another protection is an agreement to grant power of attorney by the seller to the buyer which cannot be withdrawn if all the requirements have been met for the sale and purchase, the buyer can transfer or transfer the rights even though the seller is not present at the signing the deed of sale and purchase. While, repressive legal protection, namely legal protection provided in the event of a dispute, is the aggrieved party to the sale and purchase agreement, namely the buyer actively takes legal action by filing a civil lawsuit to the local District Court to force the seller to carry

18 Philipus M. Hadjon, Perlindungan Bagi Rakyat di Indonesia, (Surabaya: PT.Bina Ilmu, 1987), 1-2.

19 Satjipto Raharjo, Ilmu Hukum , (Bandung : PT. Citra Aditya Bakti 2000), 54 
out the sale and purchase agreement for the land with the building use title, with expectation to get legal certainty and the fairest decision.

\section{BIBLIOGRAPHY}

\section{Book:}

Suharnoko, Hukum Perjanjian Teori Dan Analisis Kasus, Cetakan ke 9, (Jakarta, Kencana,2015).

Soerjono Soekanto, Sri Mamudji, Penelitia Hukum Normatif, (Depok, Rajawali Pers, 2019).

Philipus M. Hadjon, Perlindungan Bagi Rakyat di Indonesia, (Surabaya, PT.Bina Ilmu, 1987).

Satjipto Raharjo, Ilmu Hukum, (Bandung, PT. Citra Aditya Bakti, 2000).

\section{Journal:}

Akhmaddhian, Suwari, and Asri Agustiwi. "Perlindungan Hukum Terhadap Konsumen Dalam Transaksi Jual Beli Secara Elektronik Di Indonesia." UNIFIKASI: Jurnal Ilmu Hukum 3, no. 2 (2018)

Arina Ratna Paramita, Yunanto, Dewi Hendrawati, Wanprestasi Dalam Perjanjian Pengikatan Jual Beli Tanah Dan Bangunan (Studi Penelitian Pengembang Kota Semarang) Diponogoro Law Jurnal, Volume 5, Nomor 3,(2016): 3

Hamdaliah, Perlindungan Hukum Bagi Pihak Pembeli yang Beritikad Baik dalam Jual Beli Tanah, Lambung Mangkurat Law Journal, Vol 1 Issue 2, ISSN: 2502-3136 | eISSN: 2502-3128 September (2016):151

Hendri Budiyanto, Pembebanan Hak Tanggungan Terhadap Hak Guna Bangunan Dalam Perubahan Status Menjadi Hak Milik, Jurnal Repertorium, ISSN:2355-2646, Edisi 3, Januari-Juni (2015): 32

Louwson, Deddy. "Wanprestasi Pengusaha Pt. Sinar Hasil Alam Pada Pihak Penjual Dalam Perjanjian Jual Beli Tanah Hak Guna Bangunan Di Kota Pontianak." Jurnal Fatwa Hukum 2, No. 2.(2019)

Muljono, Bambang Eko. "Perlindungan Hukum Bagi Pihak Penjual Terhadap Pihak Pembeli Wanprestasi Dalam Ikatan Jual Beli Tanah." Jurnal Independent 4, no. 2 (2016)

Ni Made Utami Jayantil Nyoman DarmadhaA.A. Sri Indrawati, Batalnya Pengikatan Perjanjian Jual Bei Tanah Dan Bangunan Karena Perbuatan Melawan Hukum Yang Dilakukan Oleh PT. Srikandi,Fakultas Hukum Universitas Udayana, jurnal kerthasemaya,VOL 5 NO 1 (2017) : 4

Pertiwi, Endah. "Tanggung Jawab Notaris Akibat Pembuatan Akta Nominee Yang Mengandung Perbuatan Melawan Hukum Oleh Para Pihak." Jurnal Ius 6, no. 2 (2018)

Pramithasari, Karina. "Analisis Yuridis Terhadap Wanprestasi Perjanjian Jual Beli Tanah Di Kota Batam (Studi Kasus Nomor: 26/Pdt. G/2011/PN. BTM)." PETITA 3, no. 2 (2017).

Prayogo, Sedyo. "Penerapan Batas-Batas Wanprestasi dan Perbuatan Melawan Hukum dalam Perjanjian." Jurnal Pembaharuan Hukum 3, no. 2 (2016)

Saputra, Komang Edy Dharma. "Pembatalan Sertipikat Hak Milik Dalam Jual Beli Tanah Sebagai Akibat Wanprestasi." Jurnal Ilmiah Raad Kertha 1, no. 2 (2018)

Socha Tcefortin Indera, Ambar Budhisulistyawati Sakti Perlindungan Hukum Bagi Para Pihak Dalam Perjanjian Jual Beli Tanah Letter C Di Bawah Tangan ISSN 23374640 (Printed) 2715-5676 (Online) Jurnal Privat Law, Vol. VIII No. 1 Januari-Juni (2020) 


\section{Laws and Regulations:}

Kitab Undang-undang Hukum Perdata

Undang-Undang Dasar Negara Republik Indonesia Tahun 1945

Undang-Undang No. 5 Tahun 1960 tentang Peraturan Dasar Pokok-Pokok Agraria;

Undang - Undang Nomor 4 Tahun 1996 Tentang Hak Tanggungan Atas Tanah Beserta Benda - Benda Yang berkaitan dengan Tanah

Peraturan Pemerintah Republik Indonesia Nomor 40 Tahun 1996 Tentang Hak Guna Usaha, Hak Guna Bangunan Dan Hak Pakai Atas Tanah;

Surat Menteri Negara Agraria/Kepala Badan Pertanahan Nasional tanggal 17 September 1998, Nomor 630.1-3433 tentang Agunan Sertipikat

Case:

Perkara No. 678/Pdt.G 2014/PN.Jkt.Sel 